\title{
Revision of the flexible crinoid genus Ammonicrinus and a new hypothesis on its life mode
}

Jan Bohatý

Acta Palaeontologica Polonica 56 (3), 2011: 615-639 doi: http://dx.doi.org/10.4202/app.2010.0020

The lecanocrinid Ammonicrinus (Flexibilia) is newly interpreted based on new material from the Middle Devonian of the Rhenish Massif (Eifel and Bergisches Land, Germany). The species have echinoid-like tubercles on the attachment and on the column, which bear articulated spines. The intraspecific variability of the column is discussed for three facies-controlled morphotypes, herein classified as standard "exposed-" or "encased roller-type" and the rare "settler-type". New specimens have floating transitions between different plate sculpturing and between those individuals with none or one to several columnals with herein termed "lateral columnal enclosure extensions" on the proximal-most, barrel-like dististele and the following mesistele, which is solely distinguished by these extensions. Based on this interpretation, Ammonicrinus kongieli is evaluated as a subjective junior synonym of Ammonicrinus sulcatus. The latter species was first recognised from the Eifel (Germany). "Ammonicrinus wachtbergensis", from the upper Eifelian of the Eifel, is declared a subjective junior synonym of Ammonicrinus doliiformis . The first nearly complete specimen of Ammonicrinus kerdreoletensis is described from the lower Eifelian of Vireux-Molhain (southern Ardennes, France). Two new species are described: Ammonicrinus jankei sp. nov. and Ammonicrinus leunisseni sp. nov. A functional morphologic trend in perfecting the crown encasement by continuous modification of the lateral columnal enclosure extensions of the mesistele from the Eifelian to the Givetian, indicates a vagile benthic "predator"-driven evolution of ammonicrinids in the Eifel area. Several ammonicrinid species are herein defined as spined soft-bottom dwellers, feeding in low-intensity current water, possibly through a self-produced water flow. The first known postmortem encrusting epizoans on ammonicrinid endoskeletons are reported.

Key words: Crinoidea, Flexibilia, Ammonicrinus, Devonian, Eifel, Rhenish Massif, Germany.

Jan Bohatý [jan.bohaty@mail.com], Institut für Geologie und Mineralogie der Universität zu Köln, Zülpicher Str. 49a, D-50674 Köln, Germany. 
This is an open-access article distributed under the terms of the Creative Commons

Attribution License (for details please see creativecommons.org), which permits unrestricted use, distribution, and reproduction in any medium, provided the original author and source are credited.

For Full text $(1,917.8 \mathrm{kB})$ 